\title{
AUTO/NARRATIVE AS A MEANS OF STRUCTURING HUMAN EXPERIENCE
}

\author{
by Katarzyna Gajek
}

\section{Introduction}

The turning point concerning the narrative that took place in the twentieth century was associated with the development of reflection on the narrative and extending its scope of meaning. In addition to being the theoreticalliterary term it became a philosophical, anthropological, psychological, sociological and pedagogical category, a concept contained in the domain of history, law, politics or medicine (cf. Burzyńska, 2004, p. 12; 2008, p. 26). Creating stories, natural and characteristic for people, enabled taking up multi-faceted research, making the category of the narrative very roomy and interdisciplinary.

The concept of the narrative may occur in two basic meanings. Some researchers (e.g. Barbara Hardy, David Carr, or cognitive scientists) assume that narrative is a human cognitive structure, a kind of ability to capture events and processes changing over time in complex structures of meaning. Others (such as Alasdair MacIntyre, Charles Taylor, Anthony Giddens, Paul Ricoeur) refer to narrative as a product of culture, which is the matrix for the organization of our experiences in the narrative structure (cf. Rosner, 2003, pp. 122-123).

In the literature on the subject, we may find a variety of ways to define the narrative, which is related to adopting different underlying assumptions. Though I will not attempt to make clear-cut decisions, this article will present various, sometimes inseparable, perspectives of the category of narrative and issues related to it, in order to shed some light of the 
multiplicity of viewpoints recognizing it and disputes on its essence. Thus, my text will try to order the terms used in the narrative-biographical research.

\section{Auto/narrative-Contexts and Definitions}

The above-mentioned turning point entailed certain modifications of the previously used definitions of narrative. The theory of literature and esthetic theories that apply this category recognized it as a monologue, presenting a structured sequence of events developing over time and associated with the world presented, i.e. with the characters situated in a particular environment. The generalization of this concept contributed to its recognition as one equipped with the communication aspect of the representation of the world and the self-presentation of the subject by the subject itself. Referring to the work of contemporary philosophers (such as Martin Heidegger, Hans-Georg Gadamer and Paul Ricoeur), some people began to recognize the narrative as a way of understanding the world expressing also the dynamic and historic properties of the temporality of being. The discovery of the fact that the word 'narrare' (to tell) was formed by a transformation from the word 'gna' functioning in Sanskrit, through the Latin term 'gnarus' (having knowledge, knowledgeable) strengthened the position treating narrative as the general structure of knowledge or the general cognitive structure. The narrative in such an understanding has become an interdisciplinary concept serving the description of, inter alia, the history of philosophical ideas as well as the history and dynamics of social phenomena or processes of constructing an identity (Burzyńska, 2008, p. 27).

The term 'narrative' (Latin: narratio) means a story if it refers to an utterance presenting events that are ordered in time and have their cause and effect (dynamic elements), and a description when it describes the characters and the environment associated with these events-(static elements) (Skibińska, 2006, p. 333).

Marianne Horsdal (2004, p. 12) notes that the sequence of time and the transformation of one situation to another make the definitional and constitutive features of narrative. The sequential construction of a story comprises the cause or interpretation of the development of the events, about which the listener/reader is forced to conclude, and therefore the course of events can be interpreted and understood in many ways. Cultural axioms regarding people and the world can be ingrained in the content of various narratives, and thus be repeatedly duplicated, but each story makes a statement situated in a specific context, often saturated with emotional 
and evaluative elements, i.e. characterized by a particular perspective, plot and configuration of meanings.

Peter Alheit (2002, pp. 103-107) points out that in the course of telling a story, which is a way of reviving the past, we are obliged to follow the story-telling principles. A narrative is conducted in accordance with the pattern: "Introduction-climax-solution" and its pre-condition is that it should be worth telling. A story commenced needs to be finished ("the rule of the end"), and to make it understandable we need to tell it providing all the details ("the rule of details"), but remembering about the details we must not forget about the important things ("the rule of validity and conciseness"). Storytelling takes time and requires confidentiality as well as an intimate and friendly atmosphere, since it showcases the narrator, who shares his/her personal experiences with the listeners.

Marcin Karłowski (1996, pp. 71-72 et seq.), based on the work of Theodore R. Sarbin (1986) as well as Kenneth J. Gergen and Mary M. Gergen (1988), argues that narrative is the method applied for the purpose of organization of episodes, activities and reports concerning them by the use of the categories of time and space. It combines the facts with the products of the imagination, points to the causes of events, and also takes into account the motives driving the behavior of the characters. On the other hand, auto/narratives are created as a result of the use of the first person singular pronouns, and are therefore the outcome of a grammar rule. The pronoun ' $\mathrm{I}$ ' allows for recognizing oneself as the author of the constructed story, and its declination facilitates the description of 'me' as the leading character, whose fate is intertwined in the system of events. Therefore, auto/narratives become a tool by which people explain events external to them, representing their causal relationships, and understand themselves as the main characters. The formal traits of auto/narratives are: (i) establishing a valued punchline, (ii) selecting and ordering the events adequately to the goal set by the author, (iii) establishing causal relationships and determining the interdependencies between the participants in the interactions, and (iv) establishing a marked beginning and end of the story.

Auto/narrative organizes the experiences of an individual, anchoring him/her in the past and making his/her life purposeful and meaningful. A man telling his/her own story cites one possible version of it, depending on the context in which he/she is located. The narrator reconstructs the events by presenting the links between them, which allows for rendering the processual nature of the phenomena and provides the internal dynamics of the narrative. This retrospection is accompanied by an ongoing reflection of the narrator who continually interprets his/her own 
biography, trying to explain the personal motives or the reasons for particular situations. He/she explains, comments and valorizes past events from the current point of view undertaking, sometimes explicitly, the effort for arranging the past and the present perspective. In this way, the narrative documents the changes taking place in the biographical identity of the individual and the social process of its development (RokuszewskaPawełek, 2002, p. 56).

Narrativists have had numerous philosophical disputes, mainly concerning the relationship of narrative and experience, as well as narrative and facts. The most famous among them are those participated by 'naturalists' and 'culturalists' as well as 'realists' and 'constructivists.' Naturalists, such as Jerome Bruner (one of the founders of the concept of narrative thinking), thought that creating a story is an innate ability of human beings in whose development narrative competence precedes linguistic competence (grammar), and thus the narrative is the primary basis of cognitive processes. On the other hand, culturalists, especially those that (such as Paul Ricoeur) originated from a group of hermeneutists, argued that an experience obtains a narrative form only through the influence of cultural codes. The second conflict was associated with a difference of views between realists who claimed that facts exist objectively and autonomously towards the narrative and constructivists who were affirmative that there are no facts that exist independently of it (Burzyńska, 2008, p. 28).

Regardless of the effect of the considerations concerning the primacy of the narrative competence and the linguistic competence in human life, the thesis used by Jerome Bruner (1987), which had previously been offered by Paul Ricoeur $(1984 ; 1985 ; 1988)$ states that we have no other possible means to describe the time we have lived apart from the narrative. Alternative ways of experiencing time as the clock time, calendar time or a cyclic or serial order are not able to grasp the meanings we assign to our past. Therefore, the narrative is the only way for man to refer to his past and link it with the present attributing meaning to his own activities.

Social scientists, using the theoretical-literary comprehension of the category of narrative, evoke it in the context of autobiography, capturing it as:

- structured human experience that is the subject of research-auto/narrative is a construct of the human mind, and creating a story of the self requires constant interpretation and reinterpretation of one's experiences. Additionally, auto/narratives are converted under the influence of cultural conventions;

- product of social constructivism which is also a way of knowing intermediated by social contexts-auto/narrative text is the story of a man's 
life who talks about it, while making a simultaneous interpretation of events from the current perspective. $\mathrm{He} /$ she creates a unique autobiographical narrative, one of the possible versions of it, constructed depending on the situation. In this process, the narrator also shapes his/her identity, which, like the narratives of personal experiences may undergo disintegration. Then, it is necessary to resort to their reinterpretation and reconfiguration;

- phenomenon and the method of research-narratives as a means of structuring human experiences have a particular nature if their content is an autobiography of a specific person, at the same time, however, they reflect the social and historical context of such person's life.

- construct, which taking the form of an 'auto' expression allows a person to understand the reality and oneself in the world (including one's own situation, motives, consequences of decisions). While telling one's own story, a man uses narrative patterns, shaping his or her narrative identity (Skibińska, 2006, pp. 333-335).

\section{Auto/biography as the Content of Auto/narrative -Multiplicity of Definition Perspectives}

A narrative is a story that has an author, who guided by more or less conscious needs makes an effort to construct the history of life, thus justifying the need for telling the story (see Oleś, 2008, pp. 39-41). If the story concerns the personal experiences of the narrator (the author of the narrative and its main character are the same person), we are dealing with an autonarrative, the content of which is an autobiographical account of the author of the utterance/text, presenting his/her story. On the other hand, a biography is a 'bios' (Greek: bios-life), i.e. the course of life of a particular person or an account of its conduct established in the form of a text (Urbaniak-Zając, 2005, pp. 115-116).

Pierre Dominicé (2000) is of the opinion, however, that the content of both an autobiography and a biography is the life history of the person who is also the author and the hero. At the same time, a source of inspiration for the creation of the story is the criterion for distinguishing between these two concepts: an autobiography arises from the author's personal motivation, and the biography from the inspiration of a researcher.

In the nineteenth century, anthropologists began to use the term 'life story,' often associated with the contemporary 'autonarrative.' This term 
indicated a story whose subject is the life of an individual, who is at the same time the narrator of the story. There was also coined a term 'life history,' indicating that the content of the narrator's personal experience has been enhanced with the information from additional sources (e.g. utterances of other people, institutional documents, etc.) (Golczyńska-Grondas \& Dunajew-Tarnowska, 2006, p. 8).

Norman K. Denzin (1990, p. 68) identified a number of terms synonymous with a narrative, which were formed on the basis of different methods related to biographical research, including 'life history,' 'case history,' 'case study,' 'life story,' or 'self-story':

- lifehistory is associated with collecting data (from multiplesources), their interpretation, and then the presentation of experiences of an individual, group or social organization, with the terms used in the story; it is essential to preserve the sense and the meanings given by the person telling the history;

- case history, in contrast to life history, focuses on studying the history of a particular event or process, such as the history of the AIDS epidemic or the experiences of an alcoholic that belongs to AA;

- case study is an analysis of the specificity and uniqueness of the individual case or a number of individual cases, which illustrate the same process and make the basis for the creation of a theory, a case study can coexist with a case history and often includes a history of the life of the main characters of the related events;

- life story is a story told by the author, as opposed to the life history this does not comprise conclusions based on the later interpretive work of the researcher;

- self-story is an essential part of life story; it is a personal narrative of a certain man, situated in a specific context, often containing an account describing groundbreaking or critical life events; what is significant here is the very process of the formation of the story about one's own experiences that can be repeated many times.

Elżbieta Hałas, referring to the ideas presented by Herbert Blumer, is of the opinion that biographies are reports expressed in the first person, tackling the personal experiences of a man, which show this man as an acting figure, eagerly participating in social life (Blumer, 1949; after Hałas, 1987, p. 71). Furthermore, Hałas claims that a biography is primarily a social phenomenon (secondarily it can be a source of knowledge or the subject of research), and life in a society is related to having lived a particular biography (ibid.). In view of the fact that our existence is autobiographical, but also 
historical, new events constitute for us the context for ongoing interpretation and reinterpretation of our own lives.

An autobiography can be understood as a form of a narrative, in which the narrator and the main hero of events are the same person, and the subject of the story is the personal experience. The hermeneutic perspective of understanding narrative facilitates a look at the category of autobiography comprising two opposing views. Under the first point of view, autobiography is recognized as an account on the history of life told from a subjective perspective of the narrator, which includes, among other things, a description of the situation or participants of the events. The presented object may be a biography, conceived as a real life lived (Giza, 1991, p. 101), having an additional advantage of objectivity. According to such a standpoint, which is close to naive realism and is often subject to criticism, the life told, i.e. an autobiography, is clearly separated from the life actually lived, which makes the content of the biography. The second point of view, places no such sharp boundary between these categories. Its followers believe that we do not have a direct access to the life lived (or speaking more generally to the reality) without the mediation of the language, and thus without interpretation. Therefore, the author of the autobiographical narrative, telling the story of his/her life, uses the symbols and at the same time creates a kind of reality. The language he/she speaks becomes a carrier of personal meaning and significance (Grzegorek, 2003, pp. 214-215).

Duccio Demetrio (2000, p. 16) believes that the creation of an autobiography consists of three phases: retrospection (recalling memories of past situations), interpretation (discovery of the meaning of past events, explanation of the past, taking into account the current context), and formation of heroes and events (characteristics of the self and other heroes, presentation of the fate of people against the background of processes, phenomena, situations). A person undertaking an effort to create an autobiographical story cites some facts from the history of his/her life, rarely, however, are they a faithful reflection of the actual experiences. Recalling the experiences makes it possible to analyze them in relation to the present time, and to order as well as to remember them through the deployment of the memories in the appropriate context. Past events also serve the purpose of a reflection on the present and the future, providing a reference point for them, enriching the perspective of viewing the present day, as well as stimulating the ability to anticipate the likely situations. The past facilitates using and transforming the earlier experiences, which makes, inter alia, the basis for the learning process and deriving from one's own biography. 
Summing up the discussion on the essence of auto/biography, Anna Giza-Poleszczuk (1990, p. 96) points to the aspects that are shared by the researchers:

- auto/biography is the product of the activity performed by an individual;

- it is always subjective in nature;

- an individual constructing the auto/biography selects events that are important to him/her and then attributes certain meaning to them; creating auto/biography is a process and the way of presenting it changes during the life of an individual;

- auto/biography is affected by various factors (circumstances, situations);

- auto/biography exists thanks to the linguistic message, and therefore the way it is read and understood takes on special meaning;

- auto/biography depends on the consciousness of a man (we can talk about "constitutive nature of consciousness"), because (i) it exists only when someone tells it, (ii) imagining and understanding life is dependent on the structure of the story as well as the sense and significance contained therein.

\section{Auto/narratives of Personal Experiences}

Anthony Giddens (1991, p. 23) argues that essentially "all human experience is mediated-through socialization and in particular the acquisition of language." The ability to speak gave people the chance to ensure mutual transfer of knowledge, and the possibility of using mass communication and media allowed for experiencing events distant in time and space. Language is also closely associated with memory and the ability to reconstruct the past events, both in terms of socially fixed collective experiences and personal retrospections.

Language is a constitutive part of creating a biographical narrative. Thanks to it, an individual may dress his/her own sensations in public expression and objectify his/her individual experiences by assigning certain meaning and significance to them and ordering them in relation to previous experiences. Telling the self-story, an individual conducts social construction of the reality. A biography reflects the social world in which man lives (and which is a reference point for his ideas about himself), and it becomes a specific interpretation of the reality (Kaźmierska, 1990, p. 114).

Referring to the work of Karl Mannheim, Ralf Bohnsack (2004, p. 21 et seq.) distinguished two types of understanding the insight into verbal 
expressions (or more broadly-the mental products of a man), taking into account their double structure. They contain the public content and are therefore of 'objective' and communicative importance, as well as the nonpublic content, which acquires the proper sense only within a particular group or environment, and thus it has the conjunctive importance. The basis of conjunctive communication is the community of the experienced reality that not always is the result of personal contact and interactions, but can arise from having structurally similar experiences. The space of conjunctive experience enables direct understanding based on habitual conformity and a similar method of organizing and categorizing the experiences. The second type of communication allows for crossing the borders between different spaces of experience and is related to the communicative demonstration and explanation of different working practices. It also involves interpretation and definitional generation of reality on the basis of assigned and read motives of activity.

The acquisition of language skills and mastering linguistic rules, as well as developing narrative competences, takes place in the course of social (verbal) relationships and is dependent on these interactions. Creating a narrative is thus a social issue, even if it relates to the internal experience of the individual. Personal experiences, despite the fact that they are products of culture, give a unique, individual shape to our lives. At the same time, however, each person is physically and environmentally situated, which entails social mediation of self-understanding and interpretation of reality. We cannot talk about the social and cultural determinism, because we are able to take into account different available perspectives and negotiate meanings (Horsdal, 2004, pp. 15-16).

Biographical narratives are placed in a specific historical, cultural and social context, so they are not narrowed down to a subjective, individual experience and can be included in a broader, objectified background. They become then the trademark of their time, it does not mean, however, that they are statements of historical facts. Epochal events are subjected to interpretation and included in the narrative as determinants for the course of personal experience. This procedure allows for multithreaded analyses of biographies, as well as extending the perspective of reading them embracing various contexts (Koczanowicz, 2007, p. 38).

One of the important functions of a narrative is assigning the meaning to personal experiences, the actions taken or events. The individual interprets the circumstances, takes up reflection on the historical and socio-cultural context, often presenting them against the background of his/her own experiences. Creating a biographical narrative also allows for a distanced insight into the history of one's life. An analysis of the past 
situations with the current outlook makes it possible to redefine them, and it can also be a starting point for the work on one's own biography (Grzegorek, 2005, pp. 127-128; 2003, p. 213).

Telling one's history is related to the configuration of events, important for an individual and occurring at a particular time, into sequences. While creating a story, a man explains to himself/herself and his/her partner in the interaction, the situations which are being described and then discovers the meaning of events and constructs his/her own identity. During our lives, we build a lot of narratives about ourselves, taking into account relationships with other people, interpreting the reality and granting a specific meaning to it. The dominant narratives about the past affect our present and future (cf. Morgan, 2000). In new social situations, we create different versions of the story about ourselves for different recipients. They are dependent on cultural and collective narratives, on what other people think and say about us (cf. Horsdal, 2004, p. 21).

Gabriele Rosenthal (1990, pp. 98-99) believes that the retrospective vision of our life and the way of organizing stories are dependent on the present time and our current perspective. The situations and events that are deliberately selected from the past facilitate constructing a narrative that from our point of view is coherent, credible and meaningful, through which we can explain our earlier choices, decisions and actions, or justify our judgments or evaluations. The narrator displays these experiences placing them in the coherent context of meanings. They form a sequence of individual stories that are treated by him/her as elements integrated with one another, despite the fact that it may not be confirmed by the chronological course of the narrative.

Our understanding of the reality and our own lives can be shattered by an event 'stripped of meaning,' and then an autobiographical narrative gets destroyed. In such a situation, we need to create another, reconfigured narrative, in accordance with other interpretive assumptions to integrate new experiences with it. Our narrative competences develop gradually and derive from the discursive cultural potential. That is why we cannot create meanings in the conditions of social isolation. The presence of other people ensures the possibility of participation in the practices of communication and provides us with the opportunity to share stories (Horsdal, 2004, p. 21).

\section{Narrativeness of Biographical Experiences}

The susceptibility of personal experiences to becoming a story, or narrativeness, depends on their nature. Tragic events causing trauma are hard to be told. Talking about such moments involves enormous emotional effort, 
and the most dramatic events may be omitted or their presentation is schematic and laconic. Recalling harrowing memories very often revives the distress related to them, which is also, due to its nature, impossible to communicate (Kaźmierska, 1996, p. 86; 1999, pp. 22-23).

Narrativeness may be stimulated by certain factors. Placing the experiences in a specific sequential order facilitates describing them. Then, the background for personal experiences is a broader historical, social or cultural context, namely the events of high importance, reaching beyond an individual level that took place at a particular time. Similarly, a change in the circumstances and places of the unfolding events helps to organize one's experiences. Another factor facilitating the narrative creation process is presenting the experiences in a unique situation, detaching us from the monotony of daily life, which makes us lose the track of time. They provide a benchmark for determining the chronological order of the presented plot (Kaźmierska, 1999, pp. 24-25; 1996, p. 87).

\section{The Memory of Personal Experiences}

The ability to revive memories is formed in humans already during childhood. We are able to systematize and prioritize past experiences, taking into account their intensity. We recall past events preserving their chronological order and the categories of organizing the presentation of changes in time are cause-and-effect relationships or the terms 'before'-'after.' However, the ability to integrate experiences into a coherent structure and to distinguish the turning points in the life course appears much later (cf. Demetrio, 2000, p, 20).

Philosophical tradition associates the notion of experience with the category of memory. Memory is comprehended as a system of internalized data, the global sum of what we know and accumulate in the course of life. Collecting memories requires experiencing the reality, and therefore is connected with a particular person and his/her past. 'Playing back' past events in one's memory is a reproduction of facts, interpreted from the perspective of today (Leśniewski, 2001, pp. 141-142).

There are at least two sources of knowledge about oneself and the surrounding reality, based on the memory possessed by an individual (see Baran, 2005, p. 131). Episodic memory keeps track of the events located in time and space, experienced by us directly and the relationships between them. It provides the individual with his/her own ' $\mathrm{I}$ ', allows this person to maintain a sense of identity through being aware of the continuity of existence in time. Semantic memory makes it possible to associate facts, categorize and label information of similar nature communicated through 
language. It includes a universal knowledge of the world, without the conscious access to specific experiences that lie at its core.

According to Marianne Horsdal (2004, p. 14), autobiographical episodic memory allows us to keep the memories of ourselves as participants in various past events, and the ability to store and 'playback' words or objects is ensured by semantic memory. Our personal experiences and those that have been told to us, or read by us, have a narrative structure. Telling our own story we alternatively use the experiences (current or imagined) of others. There can also occur difficulty in determining whether we were participants in the particular event, and it has been remembered by us, or we have heard about it. Encoding, storing and replaying information serves our orientation in the present and in the future, and establishing the compatibility between the past, present and future is the ongoing pursuit of the narrative identity.

The issue of memory has also been dealt with by Kaja Kaźmierska (2007, p. 15). She distinguishes, referring to, inter alia, the findings of Marek Ziółkowski (2001), three dimensions of memory (and oblivion), which are correlated with specific categories of the memory subjects. Collective memory (official or public) is created within institutions included in the system of state and local government, social memory is created by institutions of the civil society, and biographical memory is generated by persons outside the institutional network, forming informal groups, such as family or circles of friends.

The category of autobiographical memory (cf. Niedźwieńska, 2000, pp. 111-112) refers to the memories of autobiographical facts and personal events, and it is most commonly used in three ways. It may refer to (i) a given memory system with neurobiological foundation, (ii) an umbrella term for knowledge and schemes, which make the memory bases of identity (then it is used in relation to a specific item and includes memory factors as well as social and emotional ones that are relevant at the time of the event and in the process of re-playing it), (iii) mechanisms and processes involved in remembering and identifying situations experienced by an individual (both emotional, and at the same time significant for the identity structure formation, and marginal).

Biographical memory includes personal experiences accumulated over a lifetime. The biographic character of memories on the one hand emphasizes the perspective of an individual man, and on the other concerns the continuous (re)interpretation of the experience carried out from the current point of view. Biographical memory is not knowledge about the past, it facilitates re-playing information, sensations, images or sequences of events gathered and stored in the mind. Autobiographical narrative is 
a communicative activity, recalling one of the possible versions of the past, created in a given situation and for the particular listener. Methods of storing and re-playing biographical experience are determined by the course of the life of the narrator, as well as the socio-cultural context and the collective memory resources. Collective memory, built through intergenerational transmission input, allows a person to exceed the limitations of time and space of individual experience. Biographical narratives become a field of discourse between several generations, and so the biographical memory resources comprise personal experiences as well as narratives of others. The boundaries between what was actually experienced by us and what we were told can be blurred. Socially shared memories of the past and interpretations of past events affect the process of building individual and collective identity (Kaźmierska, 2007, pp. 18-19).

People have an unusually large number of memories in their biographical memory resources. Potentially, they are available to us, however, which one and in what configuration will be recalled depends on the circumstances of the recollection process. The selection of data and the manner of re-playing information are affected by cognitive schemasavailable and active at a given time-including the general human knowledge about the reality and the image of oneself. Quarrying the memories from the storage resources is also steered through questions or guidelines generated by the narrator or his/her surroundings (Niedźwieńska, 2005, pp. 27-28).

\section{Narrative Identity}

Anthony Giddens (1991, pp.5-19) believes that building identity is a process that constitutes for an individual a specific task organized by reflexivity. Reflexive designing of "self-identity" is constantly accompanied by making choices mediated by "abstract systems," which include "symbolic tokens" ("media of exchange") and "expert systems" (knowledge). This process requires maintaining biographical narratives-coherent and forming a meaningful whole-that should be subject to ongoing verification.

Identity cannot be understood as something static and brought down to a particular trait or a set of traits that characterize a person. It is a reflectively recognized awareness of the individual, providing him/her with the durability of existence in time and space. Building personal narratives lets us reflect on the biographical continuity, because stories show the course of human life and include an account of the changes that have taken place in it over the years (despite the differences, we can still recognize an individual as the same person). The identity, shaped in the process of creating 
the narrative, embraces the way of understanding the reality, self-image and the structure of meanings, which are used by the individual (ibid., pp. 50-51, 145-146).

Identity, through which we retain a sense of empowerment and biographical consistency and continuity, may be to some extent manifested, as well as presented to others in the course of communication, through constructing and maintaining the personal narrative. Auto/narratives are extremely impermanent, they undergo constant modifications, since new experiences and events important for us must be integrated with the prior experience. Similarly, the process of identity formation is never surmounted with a ready, finite structure (Rosner, 2003, p. 42).

Designing our own identity in the late modern age is, according to Giddens (1991, pp. 181-208; see also, Mamzer, 2007a, p. 52; 2007b, p. 44), an extremely complex task. He projected a field of identity dilemmas, located between four poles, whose settlement is the condition of preserving a "coherent narrative of self-identity." These are:

- unification/fragmentation-due to the changes generated by modernity, integration trends are becoming desirable associated with modifications and protection of identity narratives, however, the diversity of contexts of interactions requires that the individual should adapt to them in his/her self-presentation, which leads to partitioning, or in the worst case, disintegration of identity;

- powerlessness/appropriation-they exist simultaneously in a dynamic relationship; the variety of social reality brings about both a sense of powerlessness in the face of external factors affecting the life of the individual and interfering in it, and an increase in human capabilities and broadening of the scope of control over the course of his/her life;

- authority/uncertainty-the existence of conflicting authorities and the lack of unquestionable sources of normative references reinforce a sense of uncertainty beyond the areas of routine activity;

- personalized experience/commodified experience-reflexive project of the self is dependent upon commodification processes that shape specific lifestyles; individuals can express themselves through choices made in the sphere of consumption and possession of certain goods or struggles with the impact of the market, individually interpreting the incoming information.

Alasdair MacIntyre (2007, p. 204 et seq.; see also, Rosner, 2003, pp. 2431) made an analysis of historical and social circumstances of constructing narrative self-representations and maintaining selfhood (strict identity). 
He noted that every story about individual life is a part of a set of stories coupled together. Therefore, we are only the co-authors of our own narratives in which other people also participate and contribute to them, "I am forever whatever I have been at any time for others-and I may at any time be called upon to answer for it," says the author of After Virtue (MacIntyre, 2007, p. 217). Similarly, our actions are important for the lives of others, we are the 'supporting cast' and partial creators of their history. Social coexistence requires some agreement on the self-narratives and the mutual recognition of different identities, and each activity, which serves as an episode in the story, should be logically explained so that it retains meaning for all people involved. Our social location and certain identifications at the level of collective life exert influence on the shape of personal narratives. Social identities are a part of our self-definitions, while in the process of socialization we learn the meanings inscribed in them, through which we read out the meaning of all the stories. Another factor crucial for the creation of self-narratives and building identity is tradition. It is a source of moral references, the starting point for the determination of the values important for a man, and supporting it ensures people situatedness in a historical context.

Charles Taylor (2012), characterizing the context of understanding the modern identity, defined it, inter alia, as something that an individual recognizes as his/her own, as something personal. Every person is involved in shaping their own identity (by abandoning the social purpose and being faithful to the imperative of self-realization), but does not make an arbitrary choice concerning it. Individual self-interpretation in the vocabulary used by Taylor $(2012,1985)$ requires self-acceptance, which arises on the basis of negotiation with the environment, one's own history and destiny, and needs social recognition, which is a prerequisite of fulfilled identity. The latter is conditional-it is largely a matter of postulativeness of the author of Sources of the Self and his unwavering confidence in man-upon the deep inherent good in us, and it "has to be woven into my understanding of my life as an unfolding story. [...] making sense of one's life as a story is also, like orientation to the good, not an optional extra; [...] our lives exist in this space of questions, which only a coherent narrative can answer. In order to have a sense who we are, we have to have a notion of how we have become, and where we are going," says Taylor (2012, p. 47).

According to Paul Ricoeur (1984; 1985; 1988), the situation of narrative communication that distinguishes man from the world of other beings, allows the storyteller to take the benefit of narrative reasoning. Creating stories about our own lives, the content of which are individual experiences, shows, among other things, our ways of interpreting situations, 
understanding others, and it is also an attempt of self-presentation and of defining ourselves. Past experiences can take the form of a narrative by referring them to cultural codes, and in connection with this, a narrative is a set of narrative codes developed within culture that allow for the presentation of our experience. It is a position that differs from the recognition of the narrative as a primordial structure of the human mind (present in the deliberations of David Carr and Roy Schafer), used and developed in the stories. Paul Ricoeur believes that understanding the story of the self and the narrative creation of individual identity is only possible thanks to the reference to the historical-literary tradition mediated by culture codes. The interpretation of texts, representing the cultural heritage, can give meaning and significance to our experiences (Rosner, 2003, pp. 131-134; Kociuba, 2007, p. 61; Mamzer, 2007a, p. 55).

The identity of man, according to the concept coined by Ricoeur, is always the narrative identity, and as such it comprises three integral elements: continuity in time (sense of stability), sense of coherence and distinctiveness from others (Mamzer, 2002, pp. 51-59):

- continuity in time is maintained by referring to autobiographical memory; identity building is a process that will never be completed and takes place in the course of the interaction between the individual and the social environment; the awareness of one's 'self,' based on the self-determination of the individual, recognized in the context of the passage of time (taking into account the time dimension allows a person to link the past with the present and the future), enables recognition of oneself as the same person (the continuity of the forms of identity is preserved) and gives us a sense of sustainability;

- a sense of coherence is a feeling of inner harmony, reasonableness and lack of contradiction between all elements of identity; each part is significant for the constitution of the awareness of one's 'self,' and its existence can be justified; fragmentation and episodic character of life trigger the possibility of unlimited creation of selfidentity, taking decisions about its shape; on the other hand, the uncertainty felt by man and fragility (eventually disintegration) of the structure of identity encourage the exploration of reference points and reducing personal responsibility;

- a sense of separateness gives evidence of man's individuality and uniqueness, enables him to distinguish himself from the others, on the other hand, it may be associated with emphasizing non-dependence, withdrawal from seeking the approval of others or lack 
of need of cherishing social ties; in the process of creating identities we are forced to choose between exposing ones autonomy (desire for individualization and non-conformism) and the drive for belonging; social acceptance and positive self-esteem support attempts to build one's own separateness.

The concept of narrative identity, developed on the basis of numerous scientific disciplines, allowed to argue redefining the understanding of human beings in the context of the debate concerning the philosophy of the subject. In the philosophical thought, there was a shift from the substantial understanding of the human as a being, characterized by certain properties, to the dynamic approach recognizing the subject as a being that develops and changes over time, and, at the same time, whose existence takes on a finite form, because it is limited by the birth and death. Anna Burzyńska (2004, p. 16) believes that the direction of changes in the philosophical thinking leads from the Cartesian assertion "I think, therefore I am" through hermeneutic "I understand, therefore I am" to a narrativist idea "I tell, therefore I am."

\section{Summary}

Generalizing the ways of defining the narrative, and thus expanding its range of meanings, allowed for the use of this category in more and more areas of expertise, but it also required determination of the constitutive characteristics.

The ways of recognizing the concept of narrative reflect a dispute concerning the primordial nature of one of human competences: linguistic or narrative. Irrespective of them, telling the history of one's own life is the only possibility to describe our experiences.

A narrative can be recognized as a monologue, which is a communicative form of self-presentation of the narrator and representation of the world as seen by him/ her. It presents a chronologically ordered sequence of events, developing over time and related to persons and events. Its content can be the life of the storyteller or other people, located in the sociocultural context, including an account of personal experiences or supplemented by information from other sources.

Narrative connects the world of individual human experience with the broader historical and socio-cultural context as regards the time perspective. The description of life is based on the distance between the retrospective point of view and the daily course of life. It is a structure significant for the narrator, which embraces his/her constant interpretation 
of the past, tailored to the current perspective. It should be mentioned that we do not recreate our experiences or events faithfully, but we reconstruct them in the course of building the narrative (auto/biographical memory is associated with the accumulation of human experiences, which are subject to constant reinterpretation depending on the course of life of the individual and his/her location). By means of the language, we present the experienced world, although not all events are possible to be displayed and are tellable. Moreover, we are also entangled in the communication processes, creating a report for a specific recipient. From all the past events, we select those that fit our interpretation of reality and our own 'self,' and also lend credence to our story. Therefore, we can create an infinite number of narratives, depending on our self-presentation and the current assessment of the situation.

The narratives comprise some version of the stored memories and fictional elements that in the studies aiming at objectification can be resolved in terms of truth and falsehood, but there are also reflected narratives of the earlier generations, situating the narrator in the historical, socio-cultural context. The autobiographical accounts are susceptible to cultural, interpersonal and language influences, and therefore become extremely perishable and undergo constant transformations, similarly to the narrative identity constructed in the course of narration.

The narrative identity allows for maintaining a unique, consistent and sustainable self-image. A man must be recognizable for himself, which confirms his continuity in time and space and the existence of a link between the past and the present. On the other hand, a man creates ever new identities that are not stable and are subject to transformations depending on the grand narratives or opinions of us, entailing changes in the interpretation. In addition to this, there coexist many narratives created by other people, in which we also act as heroes, and this requires their reconciliation and mutual acceptance of the constructed identities.

\section{References}

Alheit, P. (2002). Wywiad narracyjny. (A. Kosowska, Trans.). Teraźniejszość-Człowiek-Edukacja, 2, 103-111.

Baran, B. (2005). Zmiana przekonań na temat własnej przeszłości. In A. Niedźwieńska (Ed.), Zmiana osobowości: Wybrane zagadnienia (pp. 131-146). Kraków: Wydawnictwo Uniwersytetu Jagiellońskiego. 
Blumer, H. (1949). An Appraisal of Thomas and Znaniecki's The Polish Peasant in Europe and America. New York: Social Science Research Council.

Bohnsack, R. (2004). Metoda dokumentarna-od koniunktywnego zrozumienia do socjogenetycznej interpretacji. In S. Krzychała (Ed., Trans.), Społeczne przestrzenie doświadczenia: Metoda interpretacji dokumentarnej (pp. 17-36). Wrocław: Wydawnictwo Naukowe Dolnośląskiej Szkoły Wyższej.

Bruner, J.S. (1987). Life as Narrative. Social Research, 54, 1-17.

Burzyńska, A. (2008). Idee narracyjności w humanistyce. In B. Janusz, K. Gdowska, \& B. de Barbaro (Eds.), Narracja: Teoria i praktyka (pp. 21-36). Kraków: Wydawnictwo Uniwersytetu Jagiellońskiego.

Burzyńska, A. (2004). Kariera narracji: O zwrocie narratywistycznym w humanistyce. In W. Bolecki \& R. Nycz (Eds.), Narracja i tożsamość, Part 2: Antropologiczne problemy literatury (pp. 119-148). Series: Z Dziejów Form Artystycznych w Literaturze Polskiej, Vol. 86. Warszawa: Fundacja Centrum Międzynarodowych Badań Polonistycznych. Instytut Badań Literackich PAN.

Demetrio, D. (2000). Autobiografia: Terapeutyczny wymiar pisania o sobie. (O. Czerniawska, Pref.; A. Skolimowska, Trans.). Kraków: Oficyna Wydawnicza Impuls.

Denzin, N. K. (1990). Reinterpretacja metody biograficznej w socjologii: znaczenie a metoda $\mathrm{w}$ analizie biograficznej [Reinterpretation of the biographical method in sociology: meaning and method in biographical analysis]. In J. Włodarek \& M. Ziółkowski (Eds.; N. Nowakowska, Trans.), Metoda biograficzna w socjologii (pp. 55-69). Warszawa - Poznań: Wydawnictwo Naukowe PWN.

Dominicé, P. (2000). Learning from Our Lives: Using Educational Biographies with Adults. San Francisco: Jossey-Bass.

Gergen, K.J., \& Gergen, M.M. (1988). Narrative and the Self as Relationship. Advances in Experimental Social Psychology, 31, 17-56.

Giddens, A. (1991). Modernity and Self-Identity: Self and Society in the Late Modern Age, Cambridge: Polity Press.

Giza, A. (1991). Życie jako opowieść: Analiza materiatów autobiograficznych w perspektywie socjologii wiedzy. Wrocław: Zakład Narodowy im. Ossolińskich-Wydawnictwo Polskiej Akademii Nauk.

Giza-Poleszczuk, A. (1990). Autobiografia między symbolem a rzeczywistością. Kultura i Społeczeństwo, 1, 95-111.

Golczyńska-Grondas, A., \& Dunajew-Tarnowska, Ł. (2006). Wprowadzenie. In A. Golczyńska-Grondas \& Ł. Dunajew-Tarnowska (Eds.), Metoda biograficzna 
w doradztwie zawodowym i pracy socjalnej (pp. 7-12). Łódź: Łódzkie Towarzystwo Naukowe.

Grzegorek, A. (2005). Jak mówienie zmienia myślenie? In A. Niedźwieńska (Ed.), Zmiana osobowości: Wybrane zagadnienia (pp. 121-129). Kraków: Wydawnictwo Uniwersytetu Jagiellońskego.

Grzegorek, A. (2003). Narracja jako forma strukturyzująca doświadczenie. In K. Krzyżewski (Ed.), Doświadczenie indywidualne: Szczególny rodzaj poznania i wyróżniona postać pamięci (pp. 209-225). Kraków: Wydawnictwo Uniwersytetu Jagiellońskiego.

Hałas, E. (1987). Biografia a orientacja symbolicznego interakcjonizmu. Kultura i Społeczeństwo, 4, 71-83.

Horsdal, M. (2004). Ciało, umysł i opowieści: O ontologicznych i epistemologicznych perspektywach narracji na temat doświadczeń osobistych. (A. Zembrzuska, Trans.). Teraźniejszość-Człowiek-Edukacja, 2, 9-29.

Karłowski, M. (1996). Epizody i tożsamość. Kultura i Społeczeństwo, 4, 69-90.

Kaźmierska, K. (2007). Ramy społeczne pamięci. Kultura i Społeczeństwo, 2, 3-25.

Kaźmierska, K. (1999). Doświadczenia wojenne Polaków a kształtowanie tożsamości etnicznej: Analiza narracji kresowych. Warszawa: Wydawnictwo Instytutu Filozofii i Socjologii Polskiej Akademii Nauk.

Kaźmierska, K. (1996). Konstruowanie narracji o doświadczeniu wojennej biografii (na przykładzie analizy narracji kresowych). In M. Czyżewski, A. Piotrowski, \& A. Rokuszewska-Pawełek, Biografia a tożsamość narodowa (pp. 85-104). Łódź: Katedra Socjologii Kultury Uniwersytetu Łódzkiego.

Kaźmierska, K. (1990). O metodzie dokumentów biograficznych. Kultura i Społeczeństwo, 1, 111-118.

Kociuba, J. (2007). Narracyjna koncepcja tożsamości. In I. Borowik, K. Leszczyńska (Eds.), Wokót tożsamości: Teorie, wymiary, ekspresje (pp. 53-65). Kraków: Zakład Wydawniczy Nomos.

Koczanowicz, L. (2007). Narracja, egzystencja, doświadczenie. In E. Kurantowicz \& M. Nowak-Dziemianowicz (Eds.), Narracja-Krytyka-Zmiana: Praktyki badawcze we wspótczesnej pedagogice (pp. 35-44). Wrocław: Wydawnictwo Naukowe Dolnośląskiej Szkoły Wyższej.

Leśniewski, N. (2001). O hermeneutyce doświadczenia (na przykładzie Diltheya i Heideggera). In T. Buksiński (Ed.), Doświadczenie (pp. 141-162). Poznań: Wydawnictwo Naukowe Instytutu Filozofii Uniwersytetu Adama Mickiewicza w Poznaniu. 
MacIntyre, A. (2007). After Virtue: A Study in Moral Theory, 3rd ed. Notre Dame, Indiana: University of Notre Dame Press.

Mamzer, H. (2007a). Narracyjne formy tożsamości. In H. Mamzer (Ed.), W poszukiwaniu tożsamości: Humanistyczne rozważania interdyscyplinarne (pp. 4759). Poznań: Wydawnictwo Naukowe Uniwersytetu Adama Mickiewicza w Poznaniu.

Mamzer, H. (2007b). Tożsamość jako narracja. In J. Leoński \& U. Kozłowska (Eds.), W kregu socjologii interpretatywnej: Badania jakościowe nad tożsamościq (pp. 40-50). Szczecin: Wydawnictwo Economicus.

Mamzer, H. (2002). Tożsamość w podróży: Wielokulturowość a kształtowanie tożsamości jednostki. Poznań: Wydawnictwo Naukowe Uniwersytetu Adama Mickiewicza w Poznaniu.

Morgan, A. (2000). What is Narrative Therapy?: An easy-to-read introduction. Adelaide: Dulwich Centre Publications.

Niedźwieńska, A. (2005). Jak pamiętamy siebie z przeszłości? Konsekwencje dynamiki wspomnień dla badania zmiany osobowości. In A. Niedźwieńska (Ed.), Zmiana osobowości: Wybrane zagadnienia (pp. 25-37). Kraków: Wydawnictwo Uniwersytetu Jagiellońskiego.

Niedźwieńska, A. (2000). Pamięć autobiograficzna. In A. Gałdowa (Ed.), Tożsamość człowieka (pp. 111-126). Kraków: Wydawnictwo Uniwersytetu Jagiellońskiego.

Oleś, P.K. (2008). Autonarracyjna aktywność człowieka. In B. Janusz, K. Gdowska, \& B. de Barbaro (Eds.), Narracja: Teoria i praktyka (pp. 37-52). Kraków: Wydawnictwo Uniwersytetu Jagiellońskiego.

Rokuszewska-Pawełek, A. (2002). Chaos i przymus: Trajektorie wojenne Polakówanaliza biograficzna. Łódź: Wydawnictwo Uniwersytetu Łódzkiego.

Ricoeur, P. (1984). Time and Narrative, Vol. 1. (K. McLaughlin \& D. Pellauer, Trans.). Chicago: University of Chicago Press.

Ricoeur, P. (1985). Time and Narrative, Vol. 2. (K. McLaughlin \& D. Pellauer, Trans.). Chicago: University of Chicago Press.

Ricoeur, P. (1985). Time and Narrative, Vol. 3. (K. McLaughlin \& D. Pellauer, Trans.). Chicago: University of Chicago Press.

Rosenthal, G. (1990). Rekonstrukcja historii życia: Wybrane zasady generowania opowieści $\mathrm{w}$ wywiadach biograficzno-narracyjnych. In J. Włodarek \& M. Ziółkowski (Eds.; N. Nowakowska, Trans.), Metoda biograficzna w socjologii (pp. 97-112). Warszawa: Wydawnictwo Naukowe PWN 
Rosner, K. (2003). Narracja, tożsamość i czas. Kraków: Towarzystwo Autorów i Wydawców Prac Naukowych Universitas.

Sarbin, T.R. (1986). The Narrative as Root Metaphor for Psychology. In T.R. Sarbin (Ed.), Narrative Psychology: The Storied Nature of Human Conduct (pp. 3-21). New York: Praeger Press.

Skibińska, E. (2006). Mikroświaty kobiet: Relacje autobiograficzne. Warszawa: Wydawnictwo Uniwersytetu Warszawskiego.

Taylor, C. (2012). Sources of the Self: The Making of the Modern Identity, 12th printing. Cambridge, MA: Cambridge University Press.

Taylor, C. (1985). Self-Interpreting Animals. In C. Taylor, Philosophical Papers, Vol. 2 (pp. 45-76). Cambridge, MA: Cambridge University Press.

Urbaniak-Zając, D. (2005). Pedagogiczna perspektywa w badaniach narracyjnobiograficznych. In L. Koczanowicz, R. Nahirny, \& R. Włodarczyk (Eds.), Narracje-(Auto)biografia-Etyka (pp. 115-127). Wrocław: Wydawnictwo Naukowe Dolnośląskiej Szkoły Wyższej.

Ziółkowski, M. (2001). Pamięć i zapominanie: Trupy w szafie polskiej zbiorowej pamięci. Kultura i Społeczeństwo, 3/4, 3-23. 